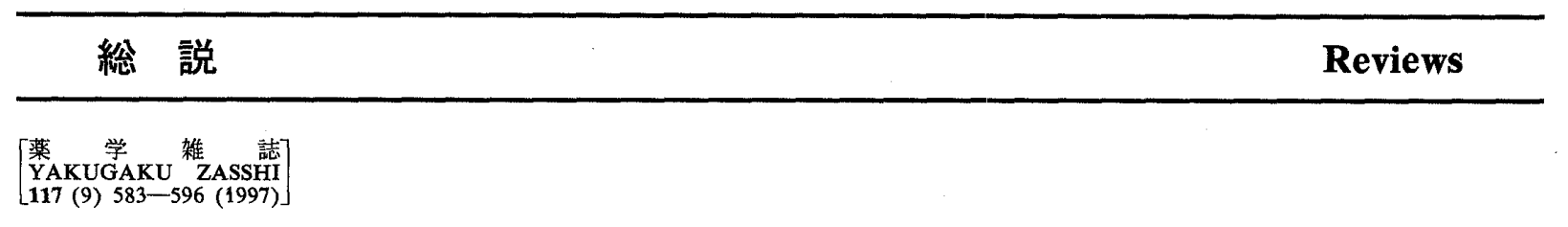

有用化合物への変換を目指した天然物の化学修飾： イオノフォア抗生物質 Monensin の化学修飾

\author{
永津明人, ${ }^{a}$ 棉原仁作 $*, b$ \\ 名古屋市立大学薬学部, ${ }^{a}$ ₹467 名古屋市瑞穗区田辺通 3-1 \\ 名城大学薬学部, ${ }^{b} \mathbf{T} 468$ 名古屋市天白区八事山 150
}

\title{
Transformation of Natural Products into More Potent Compounds: Chemical Modification of Monensin
}

\author{
Akito NAGATSU ${ }^{a}$ and Jinsaku SAKAKIBARA ${ }^{*, b}$ \\ Faculty of Pharmaceutical Sciences, Nagoya City University, ${ }^{a}$ Tanabe-dori, \\ Mizuho-ku, Nagoya 467, Japan, and Faculty of Pharmacy, Meijo \\ University, ${ }^{b}$ Yagotoyama, Tempaku-ku, Nagoya 468, Japan
}

(Received May 8, 1997)

\begin{abstract}
Monensin (1) is a representative compound of polyether ionophore antibiotics, which selectively transport $\mathrm{Na}^{+}$ions. In order to obtain potent $\mathrm{Na}^{+}$ ionophores, the modification of the carboxyl group of monensin was carried out to yield monensylamino acids (2) and monensylamino acid-1,29-lactones (3). The $\mathrm{Na}^{+}$permeability of ion through the erythrocyte membrane of 2 and 3 was evaluated by the ${ }^{23} \mathrm{Na}-\mathrm{NMR}$ method. Compound 2 showed less $\mathrm{Na}^{+}$ion transport activity than monensin, probably due to the lower lipophilicity caused by the conformational change of the chain moiety of the molecules. Although 3 showed higher lipophilisity than 1,3 had no $\mathrm{Na}^{+}$ion permeability, probably due to loss of the carboxyl group. As more lipophilic compounds possessing a carboxyl group was supposed to have more ion transport activity, 7-Oacylmonensins (8) and 7-O-alkylmonensins (11) were synthesized. Among these compounds, the value of $\mathrm{Na}^{+}$ion permeability of 7-O-benzylmonensin (11c) was 1.4 time that of 1 . Further investigation was carried out by preparing various 7 $-O$-(substituted benzyl)monensins (13), and 7-O-( $p$-ethylbenzyl)monensin (13b) exhibited the largest $\mathrm{Na}^{+}$ion permeability, about twice the value of 1 .

In order to convert monensin (1) to $\mathrm{Ca}^{2+}$ ionophore, 7-carboxylmethylmonensin (18) via protected 7-oxomonensin (15), and 25-carboxylmonensin (26) were prepared. In the course of the synthesis, $\mathbf{1 5}$ was clarified as a useful intermediate to give 7-amino and 7-alkyl derivatives. $\mathrm{Ca}^{2+}$ ion transport activities of 18 and 26 were determined by a $\mathrm{CHCl}_{3}$ liquid membrane system. 25 -carboxylmonensin (26) showed $70 \%$ of the activity of $\mathrm{Ca}^{2+}$ ionophore, lasalocid A, and compound 26 could be the lead compound for the preparation of a new $\mathrm{Ca}^{2+}$ ionophore.
\end{abstract}

Key words-monensin; sodium ionophore; 7-O-(p-ethylbenzyl)monensin; calcium ionophore; 25-carboxylmonensin

本総説は平成 9 年度退職にあたり在職中の業績を中心に記述したあのである. 


\section{はじめに}

天然の生物活性物質には，特徴的な構造や機能があるにあかかわらず，使いにくさや副作用 などの理由でその特徵を活かしきれない化合物が多くあり，古くから多くの研究者達が官能基 の変換を中心とした誘導体合成を行い，その中から医薬品としてデビューを飾った化合物も数 多くある．著者のグループでは，用途の限られた天然有機化合物として，デリス根由来でク口 マノクロマノン骨格という特徽的な構造を持っているむのの，その用途がほとんぞ「ノミ取り 粉」に限られている rotenone, 治療域が狭いという難点を持つ強心配糖体 proscillaridin, ouabain, ジギタリス葉加ら大量に得られるものの溶解性などの問題で医薬品として用いられてい ない gitoxin，防虫剤としては古くから使用されているが，医薬品の代表かと思わせるような 「カンフル棛」という名前とは裹腹に一部外用剤として用いられている他, 医薬品としてはほと んど利用されていない camphor，イオノフォアの代表的化合物であある抗生物質でありながら ニワトリのコクシジゥム予防など農薬的な利用しかされていない monensin (1) 等を素材とし

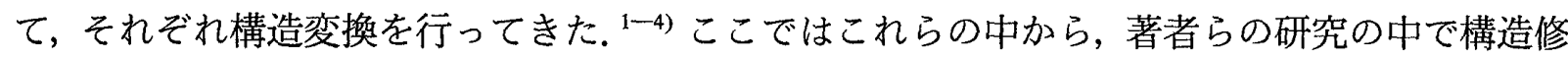
飾とイオン輸送能との関連について多くの情報が得られてきた monensin (1) について述べる.

Monensin (1, Fig. 1) は Streptomyces cinnamonensis より 1967 年単離, 構造決定された5) nigerisin, septamysin, X-206 等と並ぶポリエーテル系抗生物質の一種である.この系統の化合物 の大きな特徴として，イオノフォアとしての性質を持つことが挙げられる. Monensin (1) は酸 素原子を内側に配列させイオンを抱接し，外側は疎水性となって脂溶性の錯体を形成し（Fig. 2), ${ }^{6}$ 踈水性の生体膜を透過してイオンを濃度勾配依存的に輸送する特徵を持っている. ${ }^{7)}$ 特に $\mathrm{Na}^{+}$イオンを特異的に輸送することから, 種々の生物活性が発現する. ${ }^{8)}$ 現在, monensin (1) は ニワトリのコクシジゥム病予防薬及びウシの飼料利用率改善薬として畜産分野において利用さ れているが，作用の選択性が低いために医薬品としての応用には至っていない.

Monensin (1) の化学修飾に関する研究は当初 26 位水酸基をウレタン化し, ${ }^{9}$ その抗菌活性を 検討した例があるのみであり，また，ポリエーテル抗生物質でも laidolomycinのアシル化，ウ レタン化 ${ }^{10)}$ の例などごく少数しかなかった。

著者らは, monensin (1) がポリエーテル抗生 物質としては比較的手に入り易い化合物である ことから，より高度な利用法の開発を目的に， 化学修飾による構造とイオン輸送活性との相関 の検討を中心に研究に着手した。

\section{カルボキシル基の化学修飾とイオン輸送能の}

\section{測定}

カルボキシル基の化学修飾は擬環状構造の大 きさとコンホメーションの変換をもたらす可能 性があり，修飾した化合物の構造と $\mathrm{Na}^{+}$イオ ン輸送や生物活性との関係に興味が持たれる. カルボキシル基の修飾には生体との親和性やア ミド結合の安定性などからアミノ酸と結合させ て monensylamino acids (2) を合成することと した，後で詳述するようにアミノ酸部分が擬環 状構造形成に役に立たないことが判明したの

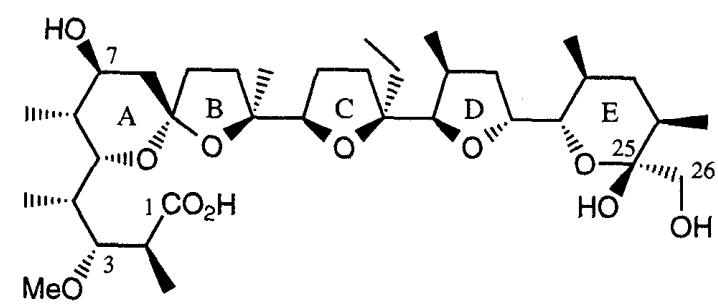

Fig. 1. Structure of Monensin (1)

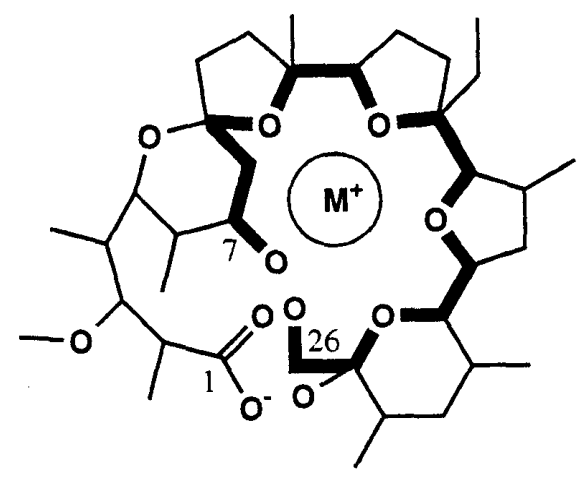

Fig. 2. Metal Complex of Monensin (1) 
でささらに2を大環状ラクトン化した monensylamino acid-1,29-lactones (3) の合成も行った. 化合物 3 はコンホメーションの自由度は失われるあのの， 2 よりあ大きな疎水性を持つことが 予想される.また, Suzuki らは monensin-1,26-lactone が優れた $\mathrm{Li}^{+}$選択的イオノフォア活性を 示すことを報告しており, ${ }^{11)}$ これより 3-結合分大きなラクトンとなる 3 は $\mathrm{Li}^{+}$よりイオン半径 の大きい $\mathrm{Na}^{+}$に対して選択的なイオノフォア活性を示すのではないかと考え, 蹯水性の大き なイオノフォアを得るという観点からあ大環状ラクトン (3) を合成した (Chart 1).

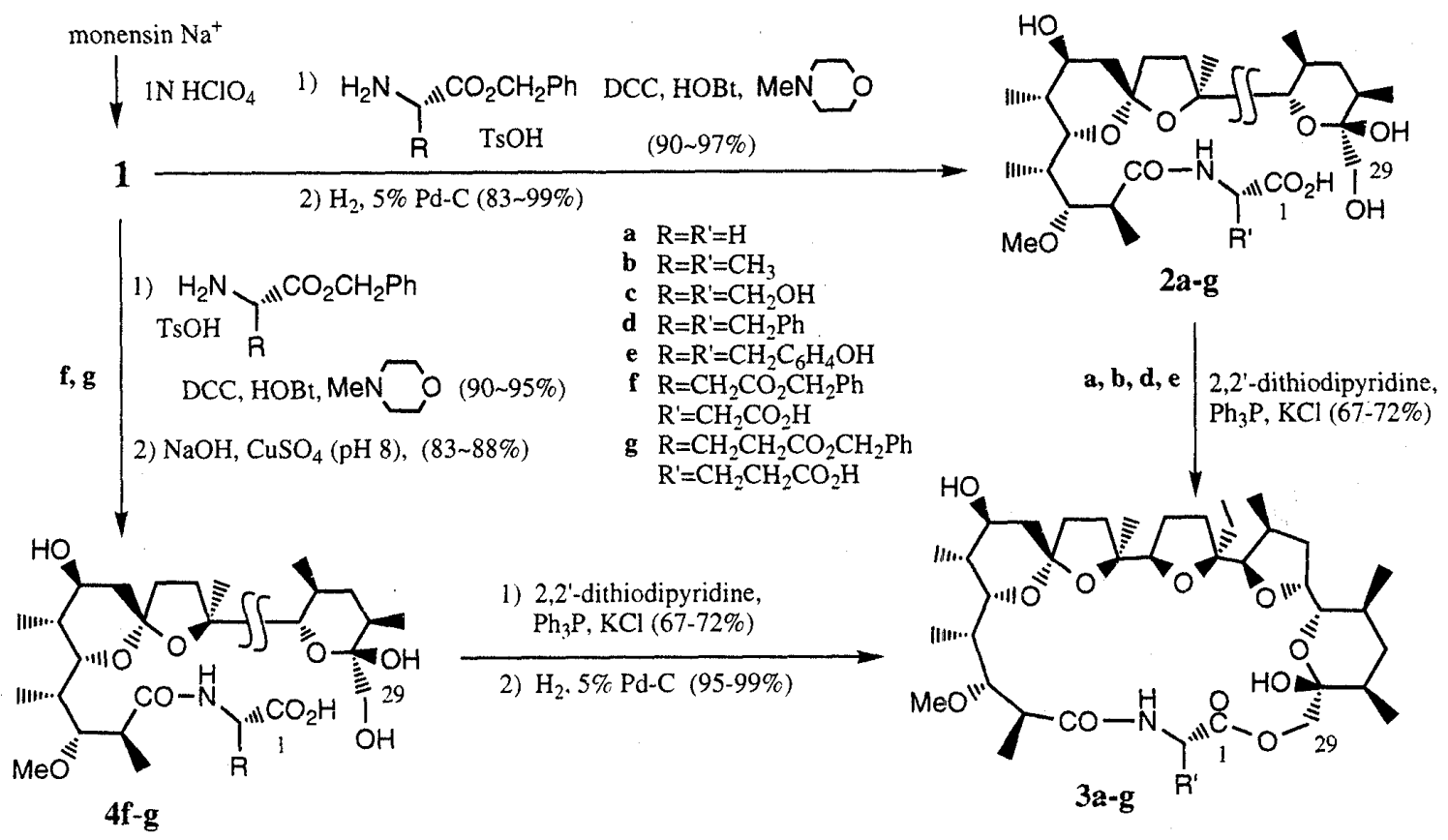

Chart 1

Monensin (1) とアミノ酸との縮合では， monensin (1) と各アミノ酸ベンジルェステルの $p$-TsOH 塩とを dicyclohexylcarbodiimide 及び 1-hydroxybenzotriazole 存在下縮合させ，各々の アミド体を得た後, 常法に従い $5 \% \mathrm{Pd}-\mathrm{C}$ 存在下で加水素分解して, 目的の monensylamino acids $(2 \mathrm{a}-\mathrm{g})$ を得た. $\left.{ }^{12}\right)$

ラクトン化反応は Corey らの試薬 ${ }^{13)}$ を用いて行った. また，2 が金属イオンを中心にして擬 環状構造をとれば, テンプレート効果 ${ }^{14)}$ により反応部位であるカルボキシル基と C-29 水酸基 とが互いに接近して反応が進行しやすくなると考え，2b を用いてラクトン化条件の検討を

A)

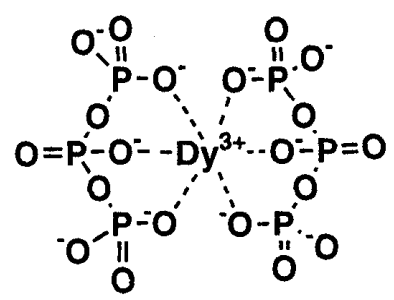

B)

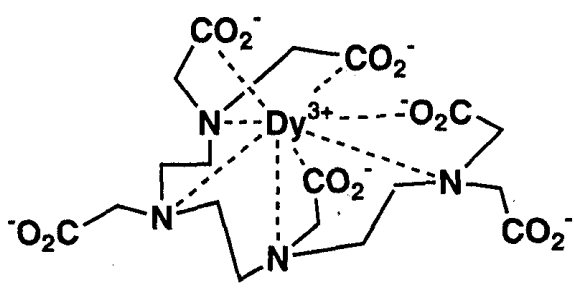

C)

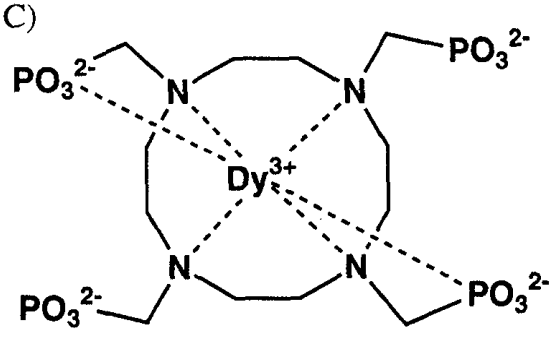

Fig. 3. Shift Reagents for ${ }^{23}$ Na-NMR Measurement

Dysprosium triphosphate (DyPPPi $\left.\mathrm{i}_{2}, \mathrm{~A}\right)$, dysprosium triethylenetetramin hexacetic acid (DyTTHA, B), and dysprosium 1,4,7,10-tetraazacyclododecane- $N, N^{\prime}, N,{ }^{\prime \prime} N^{\prime \prime \prime}$-tetraphosphonate (DyDOTP, C). 
行った. $\mathrm{Li}, \mathrm{Na}, \mathrm{K}, \mathrm{Rb}, \mathrm{Cs}, \mathrm{Ba}$ の各塩化物を添加して反応を行った結果, $\mathrm{KCl}$ 添加時に最むよい 収率で 3b が得られることが分かった。この結果から KCl を添加して 2a-eeのラクン化を行 い $\mathbf{3 a}-\mathbf{e}$ を得た. ${ }^{15)}$

化合物 $2 \mathrm{f}, \mathbf{g}$ には分子内に 2 つのカルボキシ ル基が存在するため，C-1 カルボキシル基で選 択的にラクトン化するよう別ルートによるラク トン化を行った。すなわち，まずジベンジルエ ステルを $1 \mathrm{~N} \mathrm{NaOH}, \mathrm{CuSO}_{4}$ 存在下 $\mathrm{C}-1$ ベンジ

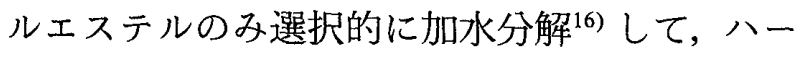
フェステル (4f, g) とした。化合物 4f, $\mathrm{g}$ のラク トン化を $\mathbf{2 a}-\mathbf{e}$ と同様に行い, 脱ベンジル化 $l$, 目的の $3 \mathbf{f}, \mathbf{g}$ を得た。

合成した化合物の膜を介したナトリウムイオ ン輸送活性を生細胞膜で測定する目的で，その モデルとして赤血球を用い，非侵襲的測定法と して ${ }^{23} \mathrm{Na}$-NMR を用いた. ${ }^{17)}$ 測定に際しては細 胞内外のナトリウムイオンのシグナルを区別す るために, 細胞膜を透過しない常磁性陰イオン 性のシフト試薬を用いた (Fig. 3). Dysprodium

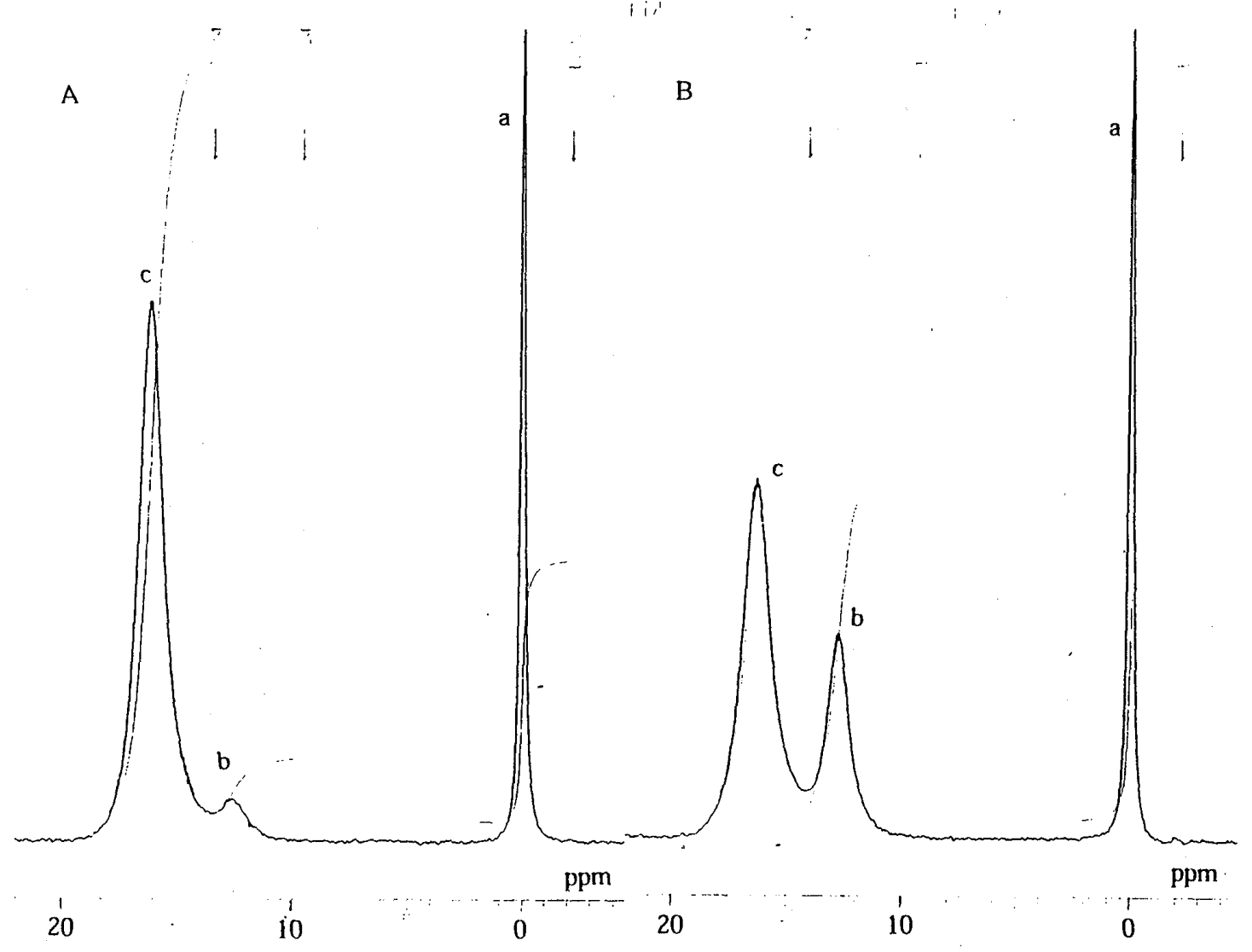

Fig. 5. ${ }^{23} \mathrm{Na}-\mathrm{NMR}$ Spectra Acquired before (A) and $90 \mathrm{~min}$ after (B) Addition of 2d

$a, b$, and $c$ indicate the signals of external reference, and intracellular and extracellular $\mathrm{Na}^{+}$ ions, respectively. 
A. Monensyiamino acids (2a-g)

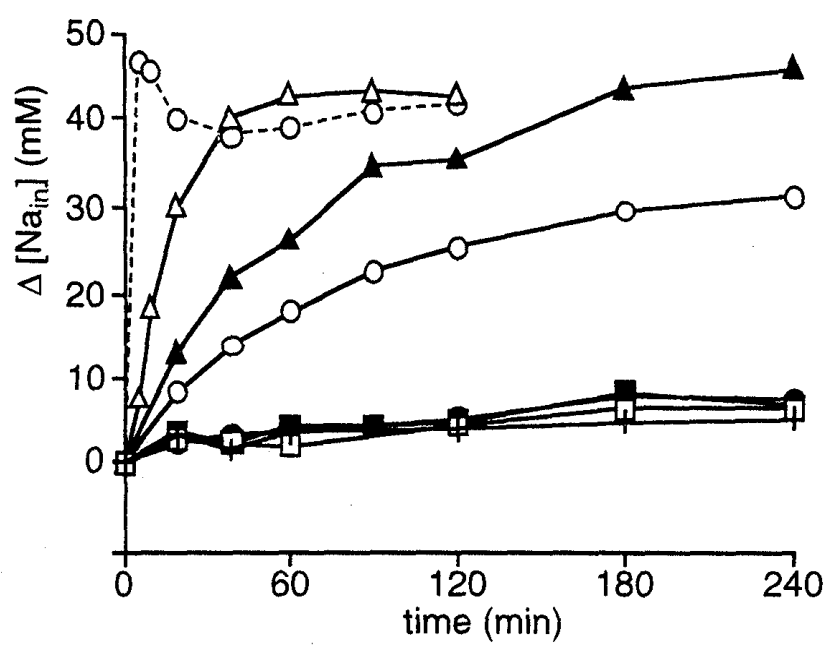

B. Lactor.es (3a-g)

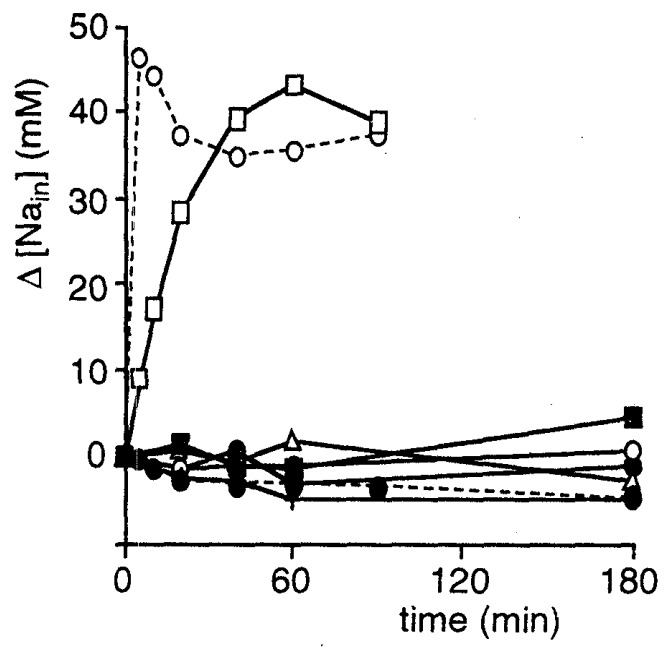

Fig. 6. Time Course of $\Delta\left[\mathrm{Na}_{\mathrm{in}}\right]$ induced by $10^{-4} \mathrm{M}$ of Monensylamino Acids $(2 \mathrm{a}-\mathrm{g}, \mathbf{A})$ and the Lactones (3a-g, B)

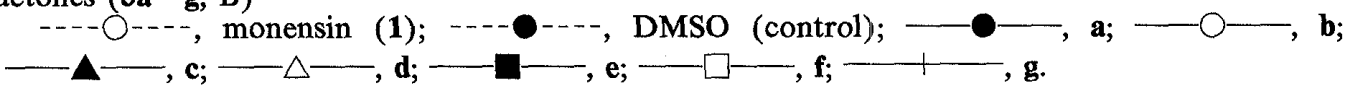

triphosphate $(\mathrm{A})^{18)}$ は外部標準のシフト試薬と して 2 重管構造の NMR チューブ (Fig. 4) の内 側の管に入れ，細胞内外のシグナルの区別のた めのシフト試薬 $\left(\mathrm{B}^{19)}\right.$ 又は $\left.\mathrm{C}^{20)}\right)$ は赤血球懸濁 液，試験サンプルと共に外側の管に入れて測定 に供した。

得られたスペクトルを Fig. 5 に示した. 細胞 内のイオンのシグナルとシフト試薬 DyTTHA で低磁場シフトした細胞外のシグナルが分離し ており，サンプルを投与後，細胞内シグナルの 積分值が増加し, 細胞外シグナルの積分值が減

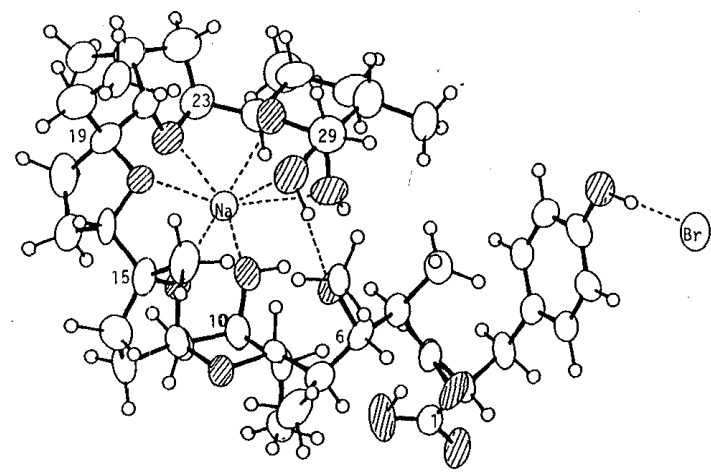

Fig. 7. ORTEP Drawing of Monensyltyrosine (2e) Sodium Bromide Complex 少していることが確認できた．外部標準シグナルの積分値を 1 とした各シグナルの積分值と， あらかじめ濃度既知の食塩水から求めた検量線をもとに細胞内外のイオン濃度を算出した。

各化合物を $10^{-4} \mathrm{M}$ 投与した際の細胞内 $\mathrm{Na}^{+}$イオン濃度の経時変化を測定した. (Fig. 6) Monensin (1) では急激な細胞内 $\mathrm{Na}^{+}$イオン濃度の上昇の後やや減少して一定值になるという 変化を示した. カルボキシル基を持つ化合物のうち $\mathbf{2 b}-\mathbf{d}, \mathbf{3 f}$ はある程度の輸送能を示したが, ジカルボン酸 $(2 \mathrm{f}, \mathrm{g})$ やカルボキシル基の無いラクトン $(3 \mathrm{a}-\mathrm{e})$ はほとんど輸送能を示さな かった．また，比較的強くイオンを輸送した化合物のイオン輸送能と分子の疎水性を比較した ところ，疎水性の大きな化合物ほどイオン輸送能が大きくなることが分かった．以上の結果か ら, monensin 誘導体のイオン輸送能の向上には抱接するイオンの安定化のためにカルボキシ ル基が存在すること，かつ分子の疎水性が大きいことが条件になることが分かった.

ところで, monensylamino acids ( $2 \mathrm{a}-\mathrm{g})$ の疎水性が向上しなかったのはなぜかについて興味 が持たれたため，結晶性のよかった monensyltyrosine (2e) の X 線結晶構造解析を行った。 その 結果，Fig. 7 の ORTEP 図に示したように， monensin (1) のようなカルボキシル基と末端水酸 
基との間で head-to-tail の擬環状構造はとっておらず，鎖状部途中のメトキシ基酸素と末端の 水酸基との間で水素結合を作って擬環状構造をとっており，縮合させたアミノ酸部分は擬環状 構造の外側に延びていることが明らかになった. ${ }^{12)}$ 他の monensylamino acids (2) む同様な構造 をとっていることが, メトキシ基のメチル炭素の ${ }^{13} \mathrm{C}-\mathrm{NMR}$ における化学シフト值が monensin (1) に比べ大きく低磁場シフトしていることから推定でき，アミノ酸部分が擬環状構造の外側 に露出することによって蹯水性が減少するあのと考えられた．このように，カルボキシル部分 の化学修飾はあまりイオン輸送能の向上には寄与しないと考えられた.

ところで, monensin (1) の数少ない化学修飾の研究の中で, 著者らと時期を同じくして monensylamino acids やその大環状ラクトンの合成を築部らが報告している. ${ }^{21)}$ イオンの選択性につ いても検討を行っているが, 光学活性な, 陽イオンのイオノフォアよいうことで光学活性なア ミンの認識素子としての機能について検討を行っている．ポリエーテル系化合物の新しい機能 として展開が可能な分野と思われる。
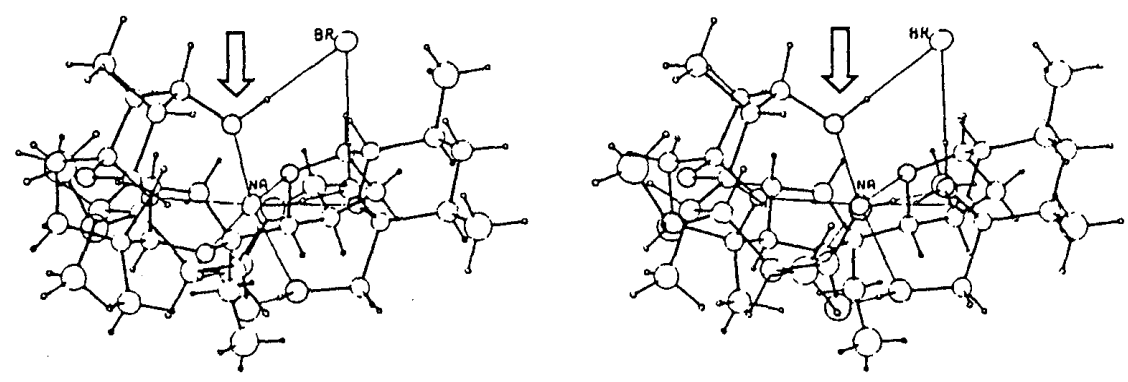

Fig. 8. The Sodium Bromide Complex of Monensin ${ }^{22)}$

C-7 Hydroxy group was at the periphery of the molecule (arrow).
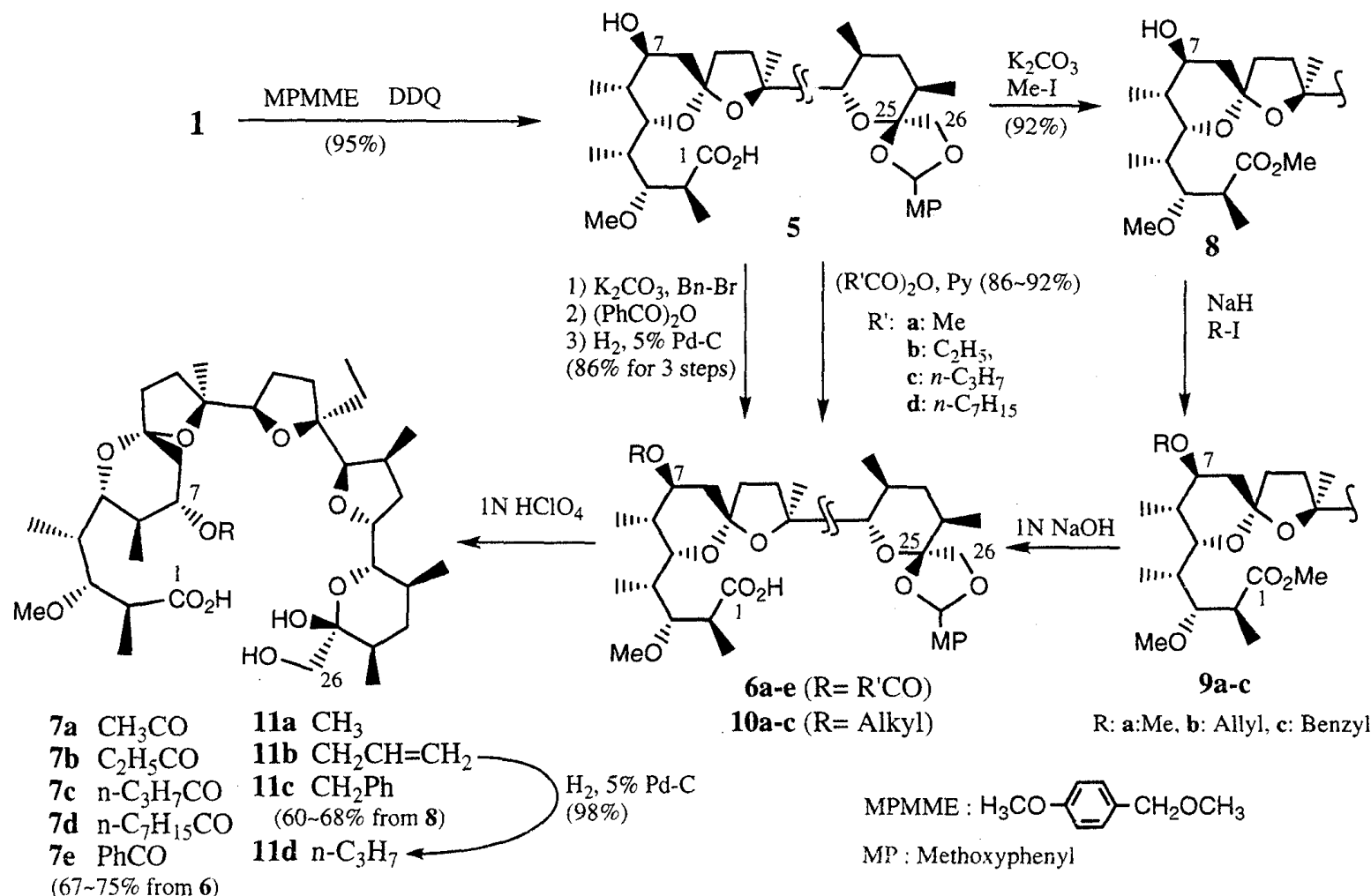

10a-c $(\mathrm{R}=\mathrm{Alkyl})$

$\mathrm{R}: \mathbf{a}: \mathrm{Me}, \mathbf{b}:$ Allyl, c: Benzyl

7b $\mathrm{C}_{2} \mathrm{H}_{5} \mathrm{CO}$

7c $\mathrm{n}-\mathrm{C}_{3} \mathrm{H}_{7} \mathrm{CO}$

11b $\mathrm{CH}_{2} \mathrm{CH}=\mathrm{CH}_{2}$

7e $\mathrm{PhCO}$

11d $n-\mathrm{C}_{3} \mathrm{H}_{7}$

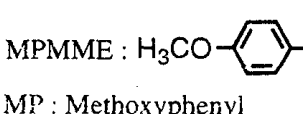

$\mathrm{CH}_{2} \mathrm{OCH}_{3}$

(67 $75 \%$ from 6$)$

Chart 2 


\section{7 位水酸基の修飾と $\mathbf{N a}^{+}$イオン輸送能}

C-7 水酸基は分子中心の穴にキレートしたイオンに配位するが， X 線結晶解析図をよく観察 すると分子の表面に存在していることが分かる (Fig. 8). ${ }^{22)}$ したがって，この部位を修飾すれ ば, 擬環状構造に変化を与えることなく分子の疎水性を上げることができると考えた。 そこで, C-7 水酸基に，置換基としてアシル基とアルキル基を導入することとした (Chart 2). ${ }^{23)}$

まず，C-25, C-26 ジオールをメトキシベンジリデンアセタールとして保護し，化合物 5 を得 た.アシル化の場合は化合物 5 に各種酸無水物を作用させた後, 脱保護して目的の 7-Oacylmonensin (7a-d) を得た. 化合物 (5) のベンゾイル化の場合, monensin 之安息香酸の混合 酸無水物が比較的安定でその分解に強いアルカリ条件が必要なため，5のカルボキシル基をべ ンジルェステルとして保護した後, benzoyl 化, カルボキシル基を脱保護, 続いて脱メトキシベ ンジリデン化して 7e を得た.

7 位水酸基へのアルキル基導入は, C-25, C-26 水酸基, カルボキシル基を保護した後, 得られ た化合物 8 を $\mathrm{NaH}$ 存在下対応するヨウ化アルキルと摫拌して 7-O-アルキル体 $(9 \mathrm{a}-\mathrm{c})$ と $\mathrm{C}-3$ メトキシ基が脱離し C-2 : C-3にオレフィンが生成した化合物を $10: 1-7: 1$ の混合物として 86-91\%の収率で得た。 この反応では，C-3×トキシ基が脱離しやすく，通常の水酸基アルキ ル化反応条件ではメトキシ脱離生成物のオレフィンが生成してしまう. 実際 Still らは, monen$\sin (1)$ の C-1-C-5 の鎖状部分官能基, 特に C-3メトキシ基のコンフォメーションに及ぼす影 響を解析する目的で， $\mathrm{NaH}, \mathrm{Bn}-\mathrm{Br}$ という条件で 7 位のベンジル化とともに C-2: C-3 にオレ フィンを生成させ，メトキシ基を他の官能基に付け替える中間体としている. ${ }^{24)}$ 著者らは，反 応温度と試薬の等量, 反応時間を注意深く選択した結果, 我々にとっては副生成物であるオレ フィンの生成を最小限とすることができた。

最後に, 9a-c のメチルエステル, メトキシベンジリデン基を順次脱保護し, 目的の 7-Oalkylmonensin $(11 \mathrm{a}-\mathrm{c})$ を 8 から収率 60-68\% で得た。化合物 11b は Pd-Cで接触水素添加し 7-O-propylmonensin (11d) に変換した。

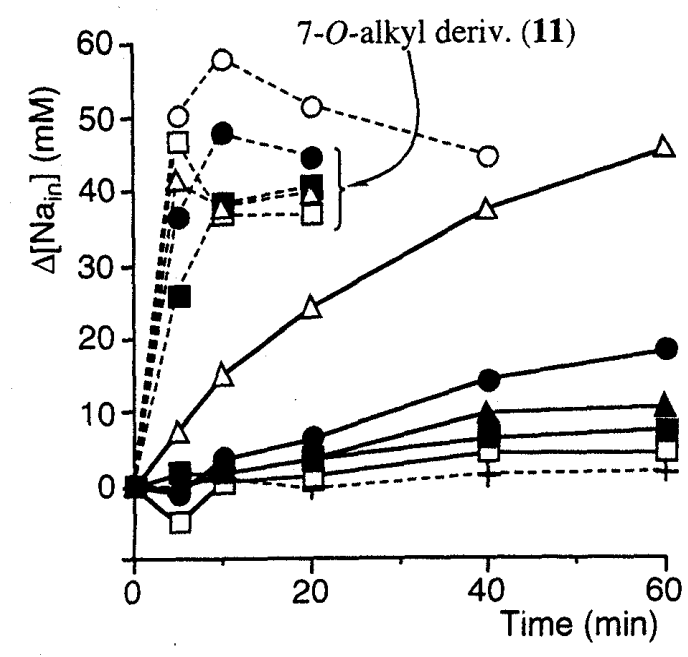

Fig. 9. Time Course of $\Delta\left[\mathrm{Na}_{\text {in }}\right]$ Induced by 1 and 7-O-Acylmonensins $(7 \mathrm{a}-\mathrm{e})$ at $10^{-5} \mathrm{M}$

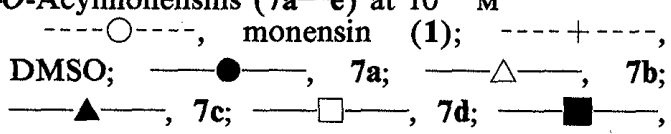

$7 e$.

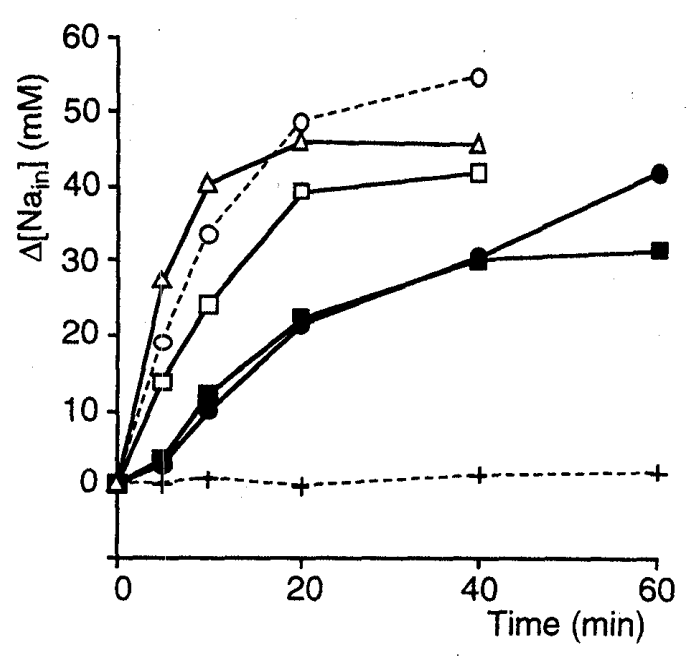

Fig. 10. Time Course of $\Delta\left[\mathrm{Na}_{\text {in }}\right]$ Induced by 1 and 7-O-Alkylmonensins $(11 \mathrm{a}-\mathrm{e})$ at $10^{-6} \mathrm{M}$

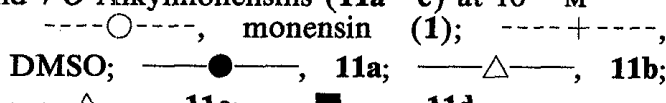


各 7-O-acyl- 及び 7-O-alkylmonensin $(7 \mathrm{a}-\mathrm{e}, 11 \mathrm{a}-\mathrm{d})$ の $\mathrm{Na}^{+}$イオン輸送能を化合物 $2 \mathrm{a}-\mathrm{g}$ と 同様に，生体膜モデルとして赤血球を用いた ${ }^{23} \mathrm{Na}-\mathrm{NMR}$ 法で検討した. 7-O-Acyl 体 (7a-e) は，10 $10^{-5} \mathrm{M}$ で検討を行ったところ 7-O-propanoyl 体 (7b) のみが輸送活性を示した (Fig. 9). 一 方, 7-O-alkyl 体 (11a-d) と monensin (1) のこの濃度での実験では初期の細胞内 $\mathrm{Na}^{+}$イオン濃 度の変化が大きすぎ，互いに比較できないことから，さらに濃度を $10^{-6} \mathrm{M}$ とて測定を行っ た。その結果，最終的な濃度の変化量はほぼ同じであったものの作用発現に重要と考えられる 細胞内イオン濃度の初期の増加速度は $11 \mathrm{a} \leqq 11 \mathrm{~d}<\mathbf{1 1 b}<$ monensin $<\mathbf{1 1 c}$ の順に大きくなり，7O-benzylmonensin (11c) の初期増加速度が monensin (1) の約 1.4 倍になることが分かった (Fig. 10).これは，7-O-alkyl 化によって分子の疎水性が大きくなったことで疎水性の細胞膜との親 和性が大きくなったためと考えられる。ささらに 11cでは，ベンゼン環上の $\pi$ 電子がイオンの補 足・放出時に，その安定化に寄与しているとも考えられる.

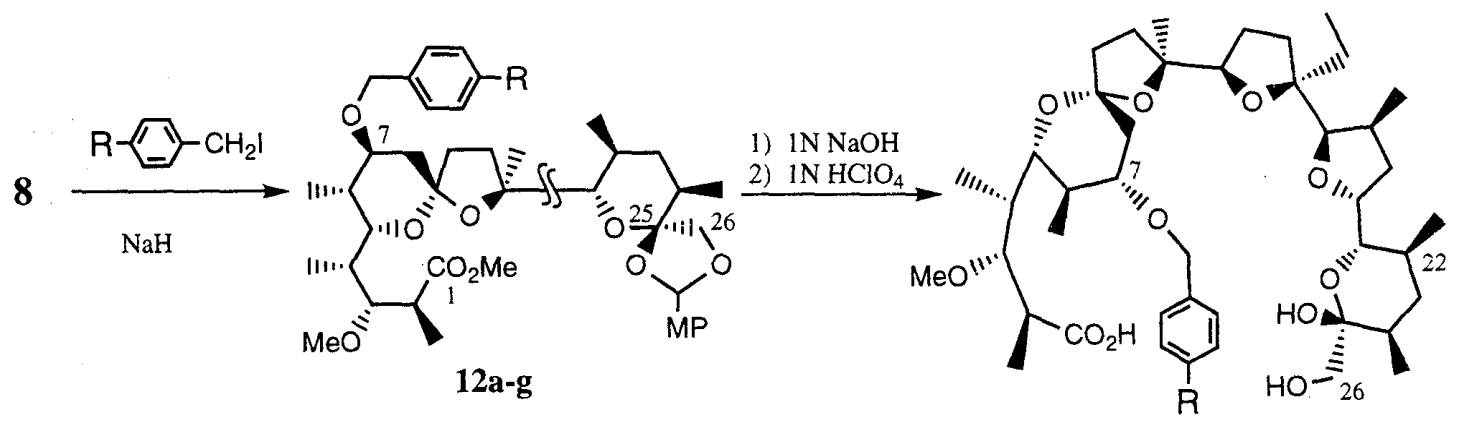

a: $\mathrm{R}=\mathrm{Me}, \mathbf{b}: \mathrm{R}=\mathrm{Et}, \mathbf{c}: \mathrm{R}=i-\mathrm{Pr}, \mathbf{d}: \mathrm{R}=t-\mathrm{Bu}$

13a-g (34 64\% from 8)

e: $\mathrm{R}=\mathrm{F}, \mathrm{f}: \mathrm{R}=\mathrm{Cl}, \mathbf{g}: \mathrm{R}=\mathrm{Br}$

Chart 3

このように, monensin (1) を越えるイオン輸送能を持つ化合物が得られたことから，さらに 疎水性の大きくし，輸送能の大きな分子を得るため，7-O-benzylmonensin (11c) をリード化合物 として種々の置換ベンジル体を得ることとした (Chart 3). ${ }^{25)}$ すなわち，7-O-alkyl 体 (11a-c) を得たときと同様にカルボキシル基と 25,26 位水酸基を保護した化合物 8 の 7 位酸素を各ヨウ 化ベンジル誘導体を用いて置換し, 脱保護して化合物 $13 \mathrm{a}-\mathrm{g}$ を得た. これら 13a-g のイオン 輸送能の測定を行ったところ Fig. 11 に示したように，ベンゼン環上置換基がエチル基の化合 物 13b が最も大きなイオン輸送能を示した．しかし，13bよりも大きな疎水性を持つ $13 \mathrm{c}$ は 13 bよりイオン輸送能が低く，さらに大きな置換基を持つ 13d はリード化合物とした 11cよりる さらに低い輸送能しか示さなかった．そこで 13bの Na 塩の結晶を作り X 線結晶解析を行った ところ, ベンゼン環上の置換基が monensin 骨格 22 位メチル基に極めて接近していることが分 かった (Fig. 12).このメチル基は benzene 環の遮蔽領域にはいっており， ${ }^{1} \mathrm{H}-\mathrm{NMR}$ において高 磁場シフトしたダブレットメチル基のシグナルが $\delta 0.11 \mathrm{ppm}$ に観測される. 他の 7-O-benzyl 誘 導体 (13a, c- - g) 屯同様に高磁場シフトしたメチル基のシグナルが観測されることから，ベン ゼン環上の置換基が大きくなるとこのメチル基との立体障害が大きくなり，そのために分子の 疎水性の向上が見られるにもかかわらず，イオン輸送能が向上しないことが分かった７ーOー Ethylbenzylmonensin (13b) の場合は, 疎水性の向上とエチル基の大きさがちょうど良いため, monensin (1) の約 2 倍という大きなイオン輸送能を発現したすのと考えられる. 


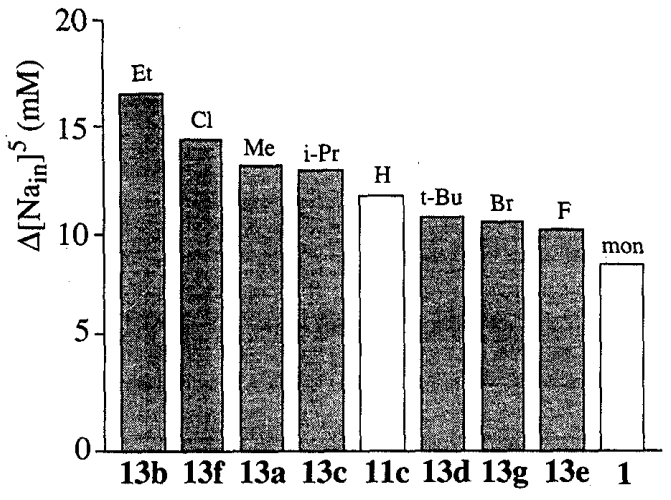

Fig. 11. Increase of Intracellular $\mathrm{Na}$ Ion Concentration within the First 5 min $\left(\Delta\left[\mathrm{Na}_{\text {in }}\right]^{5}\right)$ of 1 , 11c, and 7-O-(p-Substituted Benzyl)monensins $(13 \mathrm{a}-\mathrm{g})$

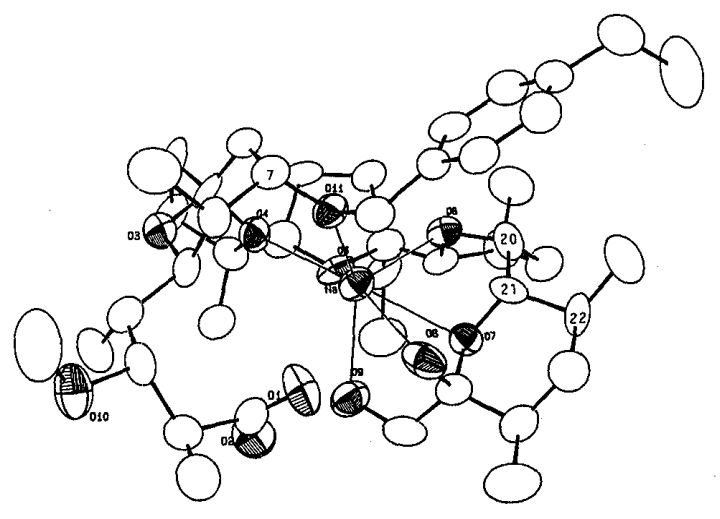

Fig. 12. ORTEP Drawing of 7-O-p-Ethylbenzylmonensin (13b) Sodium Salt

\section{2 価イオノフォアへの変換}

$\mathrm{Ca}^{2+}$ イオンは，生体内における細胞での種々の現象や細胞内での情報伝達に大きな役割を 果たしていることが多くの研究者によって解明されてきており，現在もその濃度変化や細胞内 外への流入流出に大きな関心が寄せられている。 ところで現在その $\mathrm{Ca}^{2+}$ イオンを輸送するイ オノフォアとしては A23187, lasalocid A など極く限られたものが知られているのみで，1価イ オノフォアより遙かに少ない. 生化学分野で使用されている化合物は前述の数種の化合物に限 られており，しかす非常に高価なあのである。そこで, $\mathrm{Na}^{+}$と $\mathrm{Ca}^{2+}$ のイオン半径がほぼ同じで

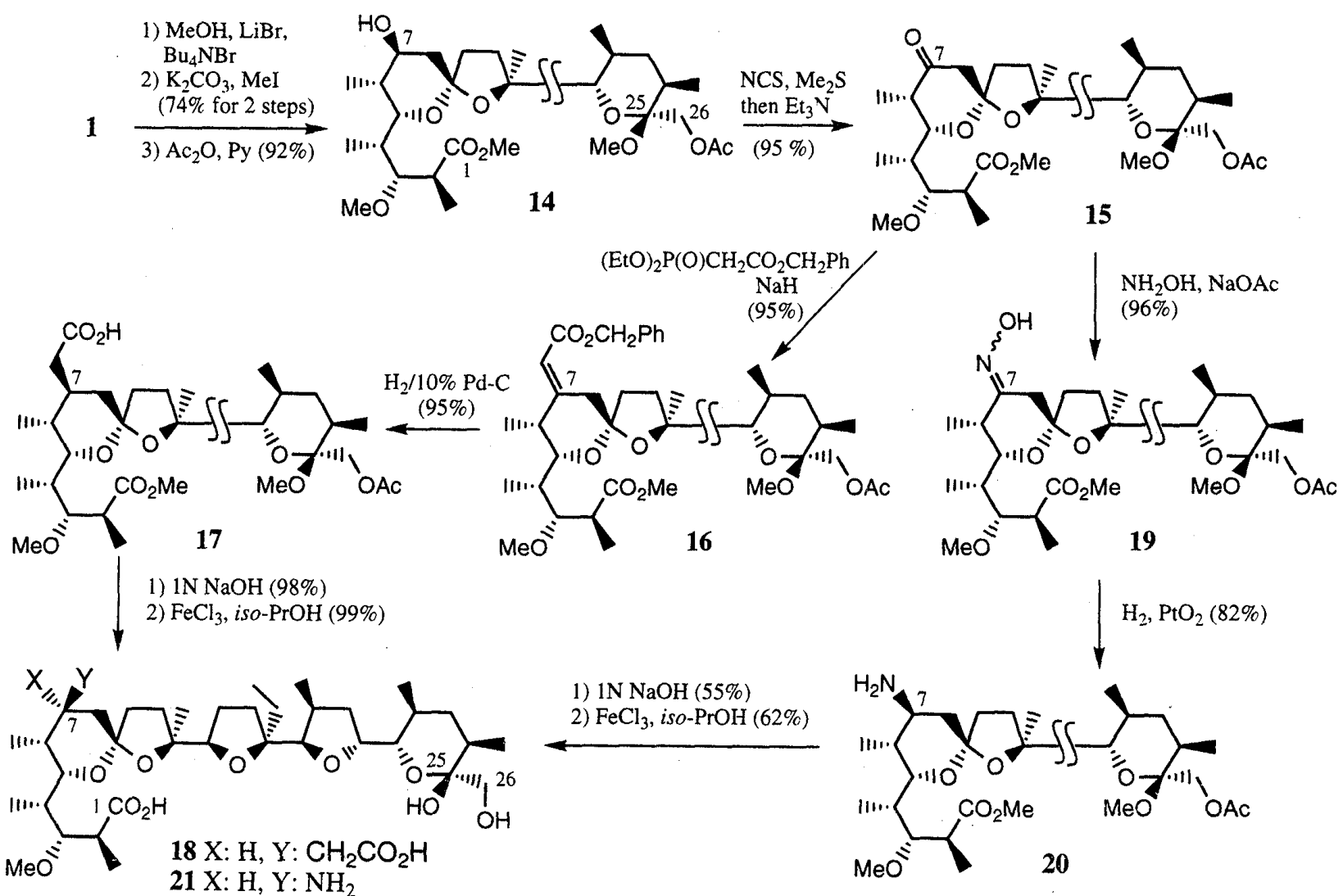

Chart 4 
あることに着目し，また，イオン輸送速度の異なる $\mathrm{Ca}^{2+}$ イオノフォアができれば，生化学用試 楽としてその速度差を利用した研究にも役立てられると考え, monensin の $\mathrm{Ca}^{2+}$ イオノフォア への変換を行った.

そこで，7位水酸基の変換による誘導体のバリエーションを増やすという目的もかねて，ま ず，7位にカルボキシル基のブロックを導入することとした (Chart 4). ${ }^{26)}$ すなわち， monensin の 25 位をメチルエーテルとして，26 位をアセチル基で，カルボキシル基をメチルエステルと してそれぞれ保護した 14 とした後，7 位水酸基を Corey-Kim 法 ${ }^{27)}$ で酸化し 7-oxo 体 (15) とし た。これに，Wittig 反応剂として benzyl diethylphosphonoacetate を作用させ 16 とした後, 還元 したところ，化合物 $\mathbf{1 7}$ を単一化合物として得ることができた。この化合物 $\mathbf{1 7}$ の脱保護を行い 目的の 7-carboxymethylmonensin (18) を収率よく得ることができた。 ところで，化合物 $\mathbf{1 8}$ への 中間体である化合物 15 は，上述したようにWittig 反応により種々の誘導体への変換が可能で ある他, hydroxylamine と反応後，還元してアミノ誘導体 (21) を得ることができ，15 から種々 のアミノ誘導体への変換が可能であることも確認できた。これらのことから15 は，これまでに 発見されているポリエーテル抗生物質と違った官能基を有する多くのバリエーションの誘導体 合成に有用な中間体として役立つと考えられる。さらに，オレフィン (16) の還元で単一の生成 物 (17) しか与えなかったこと，アミノ誘導体合成時あオキシム (19) の還元で単一の生成物 (20) しか与えず，このとき 20 の7位のプロトンの NMRにおけるカップリングパターンが monensin (1) と同様であったことから，還元生成物 (17) と20の7 位の立体配置は monensin (1) と同じであると考えられ，7位の立体が保持されたまま変換ができることが推定された.

次に，26位にカルボキシル基を構築した (Chart 5). ${ }^{28)}$ すなわち，25, 26 位ジオールをメトキ シベンジリデンアセタール，カルボキシル基をメチルエステルとしてそれぞれ保護した化合物 8 の 7 位をベンゾエートとして一旦保護した後, アセタールを脱保護して 25 位のみメチルエー
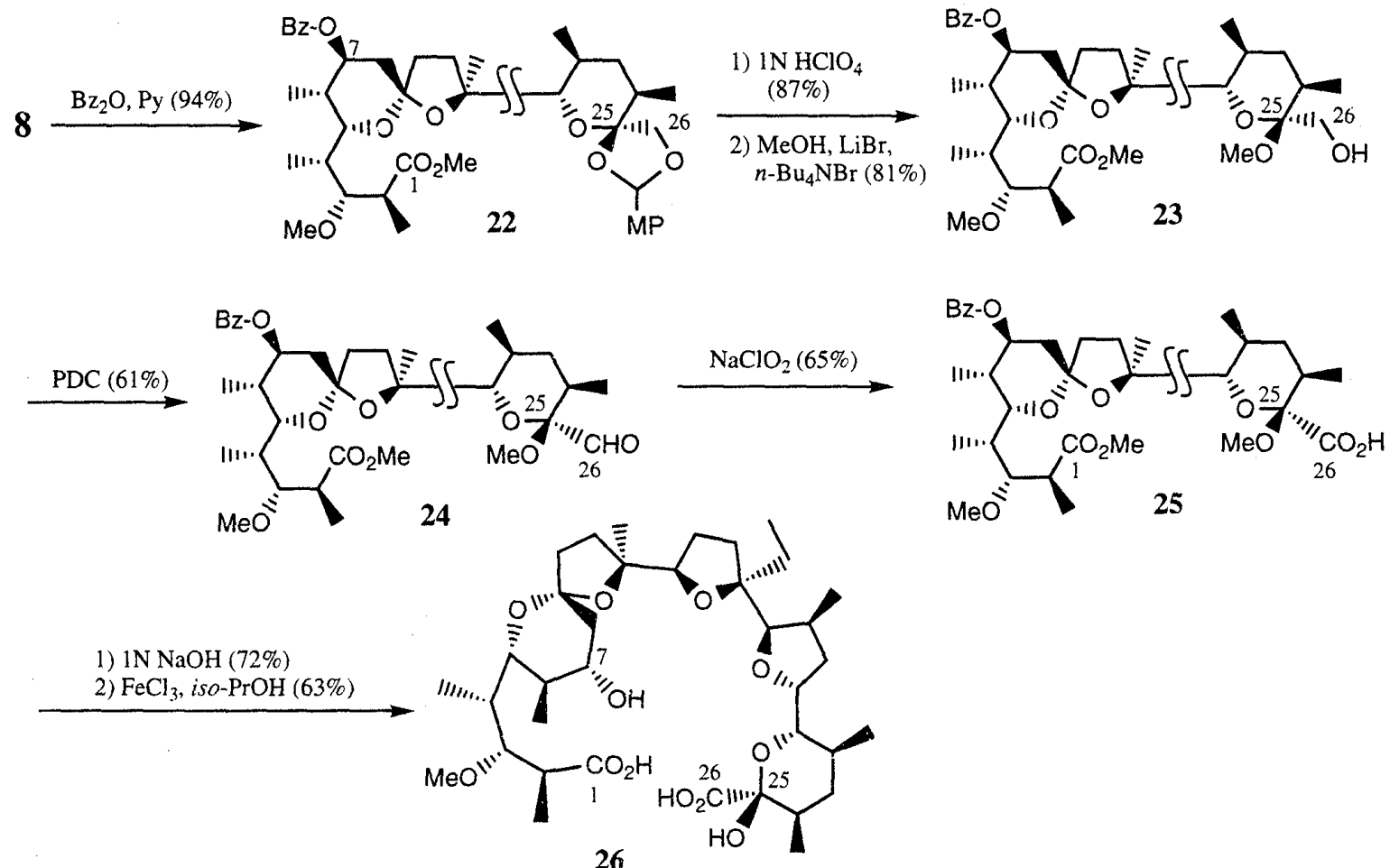

Chart 5 


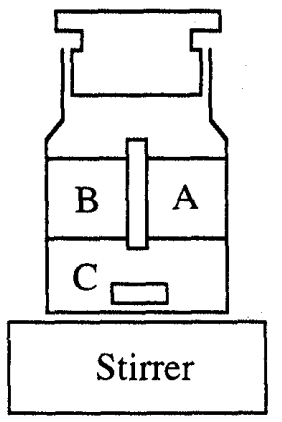

Fig. 13. Apparatus for Measurement of Ion Transport Activity by Chloroform Liquid Membrane System

A: $7 \mathrm{mmol} / 1$ calcium picrate solution; B: distilled water; $\mathrm{C}$ : $0.5 \mathrm{mmol} / 1$ test sample chloroform solution.

テルとして保護し，化合物 $\mathbf{2 3}$ 得た。これを，

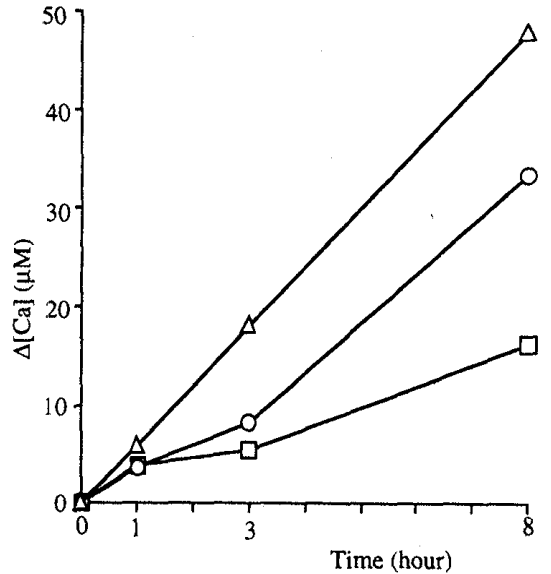

Fig. 14. Time Course of $\Delta[\mathrm{Ca}](\mu \mathrm{mol})$ Induced by Monensin (1), 25-Carboxylmonensin (26) and Lasalocid A

lasalocid A. PDC で一旦アルデヒド (24) とした後, Lindgren らの方法 $\left.{ }^{29}\right)$ でカルボン酸 (25) とした。最後にそれぞれ各保護基を脱保護して目的の 25carboxylmonensin (26) を得た。

ジカルボン酸誘導体 $(18,26)$ のイオン輸送能の検討を $\mathrm{Ca}^{2+}$ イオンについて, $\mathrm{CHCl}_{3}$ 液膜 法 ${ }^{30)}$ を用いて行った．測定には，Fig. 13 に示したようなガラス容器を用い，サンプルを溶解し

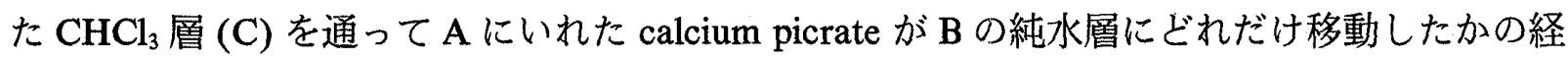
時変化を测定した。 その結果，化合物 18 は全くイオンを輸送しなかったのに対して，25carboxylmonensin (26) は対照として用いた $\mathrm{Ca}^{2+}$ イオノフォア lasalocid A の約 70\% の輸送能 を示した。

化合物 18 は，新たに構築したカルボキシル基が分子の表層にあるために疎水性が低くなり， イオン輸送能が観測されなかったと考えられる。一方, 25-carboxylmonensin (26) の場合は, ジ カルボン酸誘導体としては疎水性が大きいという特徴を持っている．これは，分子の両端に力 ルボキシル基があるため，それらがお互いに会合していると考えられ，そのために蹯水性が小 さくならないと考えられる。この化合物 26 は新たな $\mathrm{Ca}^{2+}$ イオノフォア創製の足掛かりとなる 化合物と考えている．25-Carboxylmonensin (26) をリード化合物としてさらに疎水性を高める ことによってより高いイオン輸送能を持つことができると考えており，今後の発展に期待して いる.

\section{おわりに}

以上著者のグループでは，有用化合物の創製を目指した天然物の化学修飾研究の一部として monensin の化学修飾を行ってきた. Monensin を始めとするイオノフォア抗生物質は動物薬と して依然重要な化合物群であるが，新たな用途が展開されることを期待している.

謝辞 本研究は, 著者の研究グループの各実験担当者, 共同研究の諸先生方, その他多く の方々の協力の賜であり，また文部省の科学研究費補助金など各種の助成・支援をいただいた ものであり，ここに改めて感謝する。 


\section{引用 文 献}

1) Rotenone に関するもの a) Sakakibara J., Nagai S., Akiyama T., Oda N., Ueda T., Kidouchi K., Chem. Pharm. Bull., 36, 1685-1691 (1988); b) Sakakibara J., Nagai S., Akiyama T., Ueda T., Oda N., Kidouchi K., Heterocycles, 27, 423-435 (1988); c) Sakakibara J., Nagai S., Akiyama T., Ueda T., Oda N., ibid., 24, $1109-1117$ (1986). d) Nagai S., Akiyama T., Ueda T., Oda N., Sakakibara J., ibid., 24, 913-917 (1986).

2) 強心配糖体に関するもの a) Tanase T., Nagatsu A., Murakami N., Nagai S., Ueda T., Sakakibara J., Ando H., Hotta Y., Takeya K., Asano M., Chem. Pharm. Bull., 42, 22562262 (1994); b) Murakami N., Tanase T., Nagai S., Ueda T., Sakakibara J., ibid., 39, 1330 1332 (1991); c) Tanase T., Murakami N., Nagatsu A., Sakakibara J., J. Chem. Soc., Perkin Trans. 1, 1993, 2217-2222; d) Idem, Heterocycles, 36, 1411-1416 (1993); e) Tanase T., Murakami N., Nagatsu A., Nagai S., Sakakibara J., Ando H., Hotta Y., Takeya K., Asano M., Yakugaku Zasshi, 112, 792-803 (1992); f) Tanase T., Murakami N., Nagatsu A., Sakakibara J., Biol. Pharm. Bull., 16, 431-433 (1993); g) Tanase T., Murakami N., Nagai S., Ueda T., Sakakibara J., Ando H., Hotta Y., Takeya K., Chem. Pharm. Bull., 40, 327332 (1992); h) Murakami N., Tanase T., Nagai S., Sato Y., Ueda T., Sakakibara J., Ando H., Hotta Y., Takeya K., ibid.,39, 1962-1966 (1991); i) Murakami N., Sato Y., Tanase T., Nagai S., Ueda T., Sakakibara J., Ando H., Hotta Y., Takeya K., Asano M., Yakugaku Zasshi, 111, 436-444 (1991); j) Mori J., Nagai S., Sakakibara J., Takeya K., Hotta Y., Chem. Pharm. Bull., 36, 48 -59 (1988); k) Sakakibara J., Mori J., Nagai S., Hotta Y., Takeya K., Nippon Yakurigaku Zasshi, 90, 115-123 (1987); l) Mori J., Nagai S., Sakakibara J., Takeya K., Hotta Y., Ando H., Chem. Pharm. Bull., 35, 1839-1846 (1987); m) Hotta Y., Ando H., Shirai N., Sakakibara J., Takeya K., Jpn. J. Pharmacol., 36, 205-215 (1984).

3) Gitoxin に関するもの a) Nagatsu A., Nakamura Y., Takemoto K., Shibatomi K., Nagai S., Ueda T., Sakakibara J., Fujita M., Hotta Y., Takeya K., Asano M., Hashimoto T., Asakawa Y., Hidaka H., Chem. Pharm. Bull., 45, 258-260 (1997); b) Nagatsu A., Nakamura Y., Takemoto K., Nagai S., Ueda T., Hatano K., Sakakibara J., Hashimoto T., Asakawa Y., ibid., 44, 258-260 (1996).

4) Camphor に関するものa) Nagai S., Kato N., Ueda T., Oda N., Sakakibara J., Heterocycles, 24, 907-912 (1986); b) Nagai S., Ueda T., Oda N., Sakakibara J., ibid., 20, 995-1000 (1983).

5) Agtarap A., Chamberlin J. W., Pinkerton M., Steinrauf L., J. Am. Chem. Soc., 89, 57375739 (1967).

6) Duelsler E. N., Paul I. C., "Polyether Antibiotics:Naturally Occuring Acid Ionophores," Vol. 2, ed. by Westley J. W., Marcel Dekker, New York, 1982, pp. 170-178.

7) Taylor R. W., Kauffman R. F., and Pfeiffer D. R., "Polyether Antibiotics: Naturally Occuring Acid Ionophores," Vol. 1, ed. by Westley J. W., Marcel Dekker, New York, 1982, pp. $157-170$.

8) Reed P. W., "Polyether Antibiotics: Naturally Occuring Acid Ionophores," Vol. 1, ed. by Westley J. W., Marcel Dekker, New York, 1982, pp. 186-266. 
9) a) Westley J. W., Evans R. H., Jr., Sello L. H., Troupe N., Liu C. M., Miller P. A., J. Antibiot., 34, 1248-1252 (1981); b) Westley J. W., Liu C. M., Evans R. H., Jr., Sello L. H., Troupe N., Hermann T., ibid., 36, 1195-1200 (1983).

10) a) Clark R. D., Hedden G. L., Kluge A. F., Maddox M. L., J. Antibiot., 35, 1527-1537 (1982). b) Clark R. D., Maddox M. L., Spires H. R., Long L. P., ibid., 39, 1765-1768 (1986).

11) Suzuki K., Tohda K., Sasakura H., Inoue H., Tatsuta K., Shirai T., J. Chem. Soc. Chem. Commun., 1987, 932-934.

12) Sakakibara J., Nakamura A., Nagai S., Ueda T., Ishida T., Chem. Pharm. Bull., 36, 47764784 (1988).

13) a) Corey E. J., Nicolaou K. C., J. Am. Chem. Soc., 96, 5614-5616 (1974); b) Corey E. J., Nicolaou K. C., Melvin L. S., Jr., ibid., 97, 653-654 (1974).

14) Fuhrhop J., Penzlin G., "Organic Synthesis," Verlag Chemie, Weinheim, 1983, pp. 223-238.

15) Nakamura A., Nagai S., Ueda T., Sakakibara J., Shibuya H., Kitagawa I., Chem. Pharm. Bull., 39, 1726-1730 (1991).

16) Prestidge R. L., Harding D. R. K., Battersby J. E., Hancock W. S., J. Org. Chem., 40, 3287-3288 (1975).

17) Nakamura A., Nagai S., Ueda T., Sakakibara J., Hotta Y., Takeya K., Chem. Pharm. Bull., 37, 2330-2333 (1989).

18) a) Gupta R. K., Gupta P., J. Mag. Reson., 47, 344-350 (1982); b) Wittenberg B. A., Gupta R. K., J. Biol. Chem., 260, 2031-2034 (1985).

19) a) Springer C. S., Jr., Pike M. M., Balschi J. A., Chu S. C., Ingwall J. S., Smith T. W., Circulation, 72, IV89-93 (1985); b) Pike M. M., Frazier J. C., Dedrick D. F., Ingwall J. S., Allen P. D., Springer C. S., Jr., Smith T. W., Biophys. J., 48, 159-173 (1985).

20) Sherry A. D., Malloy C. R., Jeffrey F. M. H., Cacheris W. P., Geralges C. F. G. C., J. Mag. Reson., 76, 528-533 (1988).

21) Maruyama K., Sohmiya H., Tsukube H., Tetrahedron, 48, 805-818 (1992).

22) Ward L. D., Wei K. T., Hoogerheide J. G., Popov A. I., Acta Cryst., B34, 110-115 (1978).

23) Nakamura A., Nagai S., Takahashi T., Malhan R., Murakami N., Ueda T., Sakakibara J., Asano M., Chem. Pharm. Bull., 40, 2331-2237 (1992).

24) Smith P. W., Still W. C., J. Am. Chem. Soc., 110, 7917-7919 (1988).

25) Nagatsu (née Nakamura) A., Takahashi T., Isomura M., Nagai S., Ueda T., Murakami N., Sakakibara J., Hatano K., Chem. Pharm. Bull., 42, 2269-2275 (1994).

26) Nagatsu (née Nakamura) A., Tabunoki Y., Nagai S., Ueda T., Sakakibara J., Chem. Pharm. Bull., 45, 966-970 (1997).

27) a) Corey E. J., Kim C. U., J. Am. Chem. Soc., 94, 7586-7587 (1972); b) Idem, J. Org. Chem., 38, 1233-1234 (1973).

28) Nagatsu A., Tanaka R., Sugiura T., Nagai S., Hatano K., Sakakibara J., "Symposium papers of 38th Symposium on the Chemistry of Natural Products," Sendai, Japan, 1996, pp. 733738.

29) Lindgren B. O., Nilsso T., Acta Chem. Scand., 27, 888-890 (1973). 
30) a) Koenig K. E., Lein G. M., Stuckler P.; Kaneda T., Cram D. J., J. Am. Chem. Soc., 101, 3553-3566 (1979); b) Desroches J., Dugas H., Bouchard M., Fyles T. M., Robertson G. D., Can. J. Chem., 65, 1513-1520 (1987); c) Bartsch R. A., Eley M. D., Tetrahedron Lett., 34, $5377-5380$ (1993). 